\title{
Hubungan Pengetahuan Ibu Hamil Trimester III tentang Antenatal Care Terhadap Pelaksanaan K4
}

\author{
Nurul Hikmah Annisa ${ }^{1}$, Omiati Natalia ${ }^{2}$ \\ STIKes YARSI Mataram ${ }^{1}$, Universitas Qamarul Huda Badaruddin ${ }^{2}$ \\ e-mail: ${ }^{2}$ ayoehira@gmail.com, ${ }^{2}$ omynatalia27@gmail.com
}

\begin{abstract}
Antenatal care is a pregnancy check to optimize the mental and physical health of pregnant women, monitor the progress of pregnancy to ensure the health of the mother and the development of the baby. Recognizing early on any abnormalities or complications that may occur during pregnancy. The purpose of this study was to determine the relationship between the knowledge of third trimester pregnant women about antenatal care to the implementation of K4. The design used in this research is descriptive correlation withapproach cross sectional. Sampling was done by purposive sampling. Data analysis with chi square. From the results of the study the majority of respondents had good knowledge as many as 42 respondents (73.7\%), and the majority of respondents did $K 4$ as many as 50 respondents (87.7\%). It can be concluded that there is a correlation between the knowledge of pregnant women in the third trimester of antenatal care to the implementation of K4 (value $p$ $=0.000$ ). From the results of this study it is known that with high education, the knowledge that is owned will be better and affect someone in applying it to implementation.
\end{abstract}

Keywords: knowledge, implementation of K4, third trimester pregnant women, antenatal care .

\begin{abstract}
ABSTRAK
Antenatal care adalah pemeriksaan kehamilan untuk mengoptimalkan kesehatan mental dan fisik ibu hamil, memantau kemajuan kehamilan untuk memastikan kesehatan ibu dan tumbuh kembang bayi. Mengenal secara dini adanya ketidaknormalan atau komplikasi yang mungkin terjadi selama hamil. Tujuan penelitian ini adalah untuk mengetahui hubungan pengetahuan ibu hamil trimester III tentang antenatal care terhadap pelaksanaan K4. Desain yang digunakan dalam penelitian ini adalah deskriptif korelasi dengan pendekatan cross sectional, Pengambilan sampel dilakukan dengan Purposive Sampling. Analisa data dengan chi square. Dari hasil penelitian mayoritas responden memiliki pengetahuan baik yaitu sebanyak 42 responden $(73,7 \%)$, dan mayoritas responden melakukan K4 yaitu sebanyak 50 responden $(87,7 \%)$. Dapat disimpulkan bahwa ada hubungan pengetahuan ibu hamil trimester III tentang antenatal care terhadap pelaksanaan K4 (nilai $p=0,000$ ). Dari hasil penelitian ini diketahui bahwa dengan pendidikan yang tinggi maka pengetahuan yang dimiliki akan semakin baik dan mempengaruhi seseorang dalam menerapkannya terhadap pelaksanaan.
\end{abstract}

Kata kunci: Pengetahuan, pelaksanaan K4, ibu hamil trimester III, antenatal care

\section{PENDAHULUAN}

Peningkatan persalinan oleh tenaga kesehatan yang ditargetkan pada tahun 2010 yaitu $90 \%$, menjadi program perencanaan persalinan dan pencegahan komplikasi (P4K) dalam menurunkan angka kematian ibu dan bayi. Program ini merupakan bagian dari Making Pregnancy Saver (MPS) yang mendorong ibu hamil untuk memeriksakan kehamilan, bersalin, pemeriksaan nifas dan bayi yang dilahirkan oleh tenaga kesehatan yang terampil. Pemeriksaan awal yang dilakukan berupa pemeriksaan antenatal care. ${ }^{(2)}$

K4 adalah kontak ibu hamil dengan tenaga kesehatan yang keempat (atau lebih), untuk mendapatkan pelayanan antenatal sesuai standar yang ditetapkan. Cakupannya adalah ibu-ibu hamil yang telah memperoleh pelayanan antenatal sesuai dengan standar paling sedikit 4 kali (minimal satu kali pada trimester I, satu kali pada trimester II, dan dua kali pada trimester III umur kehamilan) oleh tenaga kesehatan di satu wilayah kerja pada kurun waktu tertentu. ${ }^{(3)}$

Pemeriksaan antenatal care adalah pemeriksaan kehamilan yang dilakukan untuk memeriksa kehamilan ibu dan bayinya secara berkala, yang diikuti dengan upaya memantau kemajuan kehamilan, memastikan kesehatan fisik, mental, dan sosial ibu juga janin, serta mengenali secara dini adanya ketidaknormalan yang mungkin terjadi pada kehamilan. ${ }^{(3)}$

Pemeriksaan antenatal care yang dianjurkan kepada ibu hamil minimal 4 kali selama hamil antara lain: kehamilan trimester pertama ( $<14$ minggu) satu kali kunjungan, kehamilan trimester kedua (14-28 minggu) satu kali kunjungan, dan kehamilan trimester ketiga (28-36 minggu dan sesudah minggu ke 36) dua kali kunjungan. Walaupun demikian disarankan 
kepada ibu hamil untuk memeriksakan kehamilannya dengan jadwal sebagai berikut: sampai dengan kehamilan 28 minggu periksalah empat minggu sekali, kehamilan 28-36 minggu perlu pemeriksaan dua minggu sekali, kehamilan 36-40 minggu setiap satu minggu sekali dan apabila terdapat keluhan- keluhan tertentu. (3)

Kunjungan antenatal care yang belum optimal mengakibatkan risiko dan komplikasi kehamilan tidak terdeteksi secara dini, kunjungan antenatal minimal 4 kali merupakan salah satu upaya untuk menurunkan komplikasi yang berhubungan dengan kehamilan, persalinan, dan nifas pada ibu dan bayi baru lahir. Pemeriksaan antenatal care juga dipengaruhi oleh perilaku ibu hamil yang pada dasarnya terbentuk dari dua faktor yaitu, faktor internal meliputi tingkat pengetahuan (kecerdasan), tingkat emosi, sikap, motivasi, dan faktor eksternal meliputi lingkungan dan pelayanan kesehatan. Jadi perilaku ibu hamil dalam merawat kehamilannya juga dipengaruhi oleh pengetahuan terhadap kehamilannya. ${ }^{(9)}$ berdasarkan hasil penelitian yang dilakukan oleh Kusuma (2018) menunjukkan bahwa ibu hamil yang memiliki pengetahuan cukup cenderung patuh dalam pelaksanaan kunjungan K4. ${ }^{(7)}$

Masih belum tercapainya cakupan K4, salah satunya disebabkan karena pemahaman tentang pedoman kesehatan ibu dan bayi khususnya kunjungan pemeriksaan yang masih kurang. Pada tahun 2016, cakupan kunjungan K4 dan upaya perjalanan kesehatan terhadap ibu hamil di Lombok Barat mencapai 80,48\%, sedangkan pada tahun 2017 mencapai 89,78\%, namun hal ini masih dibawah target nasional yang menargetkan tahun 2018 yaitu $95 \%$. $^{(4)}$

Berdasarkan uraian tersebut peneliti tertarik melakukan penelitian tentang pengetahuan ibu hamil tentang antenatal care dan kunjungan antenatal care terutama kunjungan 4 (K4), dari indikator dapat diketahui cakupan pelayanan antenatal care secara lengkap (memenuhi standar pelayanan) yang dilakukan oleh ibu hamil. Oleh sebab itu, peneliti ingin mengatahui "Bagaimana hubungan pengetahuan ibu hamil trimester ketiga tentang antenatal care terhadap pelaksanaan K4 di Puskesmas Gerung”.

\section{METODE}

Desain penelitian ini bersifat Deskriptif Korelasi, dengan pendekatan cross sectional. Rancangan dalam penelitian ini untuk mengidentifikasi hubungan pengetahuan ibu hamil trimester III tentang antenatal care terhadap pelaksanaan K4.

Penelitian dilaksanakan di Puskesmas Gerung dimulai pada September 2019 sampai dengan Juni 2020. Populasi pada penelitian ini adalah ibu hamil trimester III di Puskesmas Gerung sebanyak $67 \mathrm{ibu}$ hamil. Teknik sampling menggunakan purposive sampling hingga didapatkan jumlah sampel dalam penelitian ini sebanyak 57 ibu hamil trimester III yang melakukan K4. Pengumpulan data dilaksanakan dengan bantuan kuesioner. Kuesioner tersebut berisi pertanyaan mengenai informasi identitas responden, kemudian bagian instrument lain berisi pernyataan untuk mengidentifikasi pengetahuan ibu hamil trimester III yang disesuaikan dengan tujuan penelitian. Pengujian data dilakukan dengan menggunakan uji statistik chi-square untuk mengatahui hubungan antara variable dependen dengan variable independen.

\section{HASIL}

Untuk mengidentifikasi pengetahuan ibu hamil trimester III tentang antenatal care terhadap pelaksanaan K4, peneliti menggunakan kuesioner yang berisikan 20 pernyataan pengetahuan dan pelaksanaan K4 dilihat berdasarkan jumlah $\mathrm{K} 4$. Berikut ini akan dijabarkan mengenai hasil penelitian tersebut yaitu karakteristik responden, pengetahuan ibu hamil trimester III tentang antenatal care, dan pelaksanaan K4 di Puskesmas Gerung.

1. Karakteristik responden

Berdasarkan tabel 1, dari hasil penelitian didapatkan dari 57 responden. Menunjukkan mayoritas umur responden antara 21 - 34 tahun yaitu sebanyak 44 responden $(77,2 \%)$. Mayoritas paritas responden primigravida yaitu sebanyak 22 responden $(38,6 \%)$, mayoritas pendidikan responden SMA yaitu 26 responden $(45,6 \%)$, dan mayoritas pekerjaan responden IRT yaitu 37 responden $(64,9 \%)$.

Tabel 1. Distribusi frekuensi responden

\begin{tabular}{|c|c|c|c|}
\hline No & $\begin{array}{c}\text { Data } \\
\text { Demografi }\end{array}$ & Frekuensi & $\begin{array}{c}\text { Persentase } \\
(\%)\end{array}$ \\
\hline 1 & $\begin{array}{l}\text { Umur } \\
<20 \text { tahun } \\
21-34 \text { tahun } \\
>35 \text { tahun }\end{array}$ & $\begin{array}{r}6 \\
44 \\
7\end{array}$ & $\begin{array}{l}10,5 \\
77,2 \\
12,3\end{array}$ \\
\hline 2 & $\begin{array}{l}\text { Paritas } \\
\text { Primigravida } \\
\text { Multigravida } \\
\text { Grademultigravi } \\
\text { da }\end{array}$ & $\begin{array}{l}22 \\
20 \\
15\end{array}$ & $\begin{array}{l}38,6 \\
35,1 \\
26,3\end{array}$ \\
\hline 3 & $\begin{array}{l}\text { Pendidikan } \\
\text { SD } \\
\text { SMP } \\
\text { SMA } \\
\text { Perguruan } \\
\text { Tinggi } \\
\end{array}$ & $\begin{array}{c}7 \\
15 \\
26 \\
9\end{array}$ & $\begin{array}{l}12,3 \\
26,3 \\
45,6 \\
15,8\end{array}$ \\
\hline 4 & $\begin{array}{l}\text { Pekerjaan } \\
\text { IRT } \\
\text { PNS } \\
\text { Wiraswasta }\end{array}$ & $\begin{array}{r}37 \\
9 \\
11\end{array}$ & $\begin{array}{l}64,9 \\
15,8 \\
19,3\end{array}$ \\
\hline
\end{tabular}


2. Pengetahuan Ibu Hamil Trimester III tentang Antenatal Care

Berdasarkan tabel 2, dari hasil penelitian pengetahuan ibu hamil trimester III tentang antenatal care dari 57 responden bahwa mayoritas memiliki pengetahuan baik sebanyak 42 responden $(73,7 \%)$

Tabel 2. Distribusi frekuensi pengetahuan ibu hamil trimester III tentang antenatal care

\begin{tabular}{|c|c|c|}
\hline Kategori & Frekuensi & Persentase (\%) \\
\hline Baik & 42 & 73,7 \\
\hline Kurang & 15 & 26,3 \\
\hline Total & 57 & 100 \\
\hline
\end{tabular}

3. Pelaksanaan K4

Berdasarkan tabel 3 distribusi frekuensi berdasarkan jumlah pelaksanaan K4 ibu hamil trimester III di Puskesmas Gerung, didapatkan mayoritas responden melakukan $\mathrm{K} 4$ sebanyak 50 responden $(87,7 \%)$ dan minoritas responden tidak melakukan K4 sebanyak 7 responden (12,3\%).

Tabel 3. Distribusi Frekuensi Berdasarkan Jumlah K4 Ibu Hamil Trimester III

\begin{tabular}{|c|c|c|}
\hline Kategori & Frekuensi & $\begin{array}{c}\text { Persentase } \\
(\mathbf{\%})\end{array}$ \\
\hline Dilaksanakan & 50 & 87,7 \\
\hline $\begin{array}{c}\text { Tidak } \\
\text { dilaksanakan }\end{array}$ & 7 & 12,3 \\
\hline Total & 57 & 100 \\
\hline
\end{tabular}

4. Hubungan pengetahuan ibu hamil trimester III tentang antenatal care terhadap pelaksanaan $\mathrm{K} 4$

Berdasarkan tabel 4, hasil penelitian didapatkan bahwa analisis hubungan antara pengetahuan ibu hamil trimester III tentang antenatal care terhadap pelaksanaan $\mathrm{K} 4$ diperoleh: dari 42 berpengetahuan baik memiliki pelaksanaan baik yaitu 41 responden $(97,6 \%)$, dan yang berpengetahuan baik dengan pelaksanaan kurang yaitu 1 responden $(2,4 \%)$. Sedangkan dari 15 responden berpengetahuan kurang memiliki pelaksanaan baik yaitu 9 responden $(60,0 \%)$ dan yang berpengetahuan kurang dengan pelaksanaan kurang yaitu 6 responden $(40,0 \%)$.

Hasil analisis hubungan antara pengetahuan ibu hamil trimester III tentang antenatal care terhadap pelaksanaan $\mathrm{K} 4$ diperoleh nilai $\mathrm{p}=0,000$. Hal ini berarti ada hubungan antara pengetahuan ibu hamil trimester III tentang antenatal care terhadap pelaksanaan $\mathrm{K} 4$.
Table 4 Hubungan pengetahuan ibu hamil trimester III tentang antenatal care terhadap pelaksanaan $\mathrm{K} 4$

\begin{tabular}{|c|c|c|c|c|c|c|c|}
\hline \multirow{2}{*}{$\begin{array}{c}\text { Pengetah } \\
\text { uan }\end{array}$} & \multicolumn{3}{|c|}{$\begin{array}{c}\text { Pelaksanaan K4 } \\
\text { Dilaksan } \\
\text { akan }\end{array}$} & $\begin{array}{c}\text { Tidak } \\
\text { dilaksana } \\
\text { kan }\end{array}$ & \multicolumn{2}{|c|}{ Total } & \multirow{2}{*}{$\begin{array}{c}\text { Nilai } \\
\text { p }\end{array}$} \\
\cline { 2 - 7 } & $\mathbf{F}$ & \% & F & \% & F & \% & \\
\hline Baik & 41 & 97,6 & 1 & 2,4 & 42 & 100 & \multirow{2}{*}{0,00} \\
\hline Kurang & 9 & 60,0 & 6 & 40,0 & 15 & 100 & 0 \\
\hline Total & 50 & 87,7 & 7 & 12,3 & 57 & 100 & \\
\hline
\end{tabular}

\section{PEMBAHASAN}

Berdasarkan tabel 2 diketahui dari 57 responden mayoritas responden memiliki pengetahuan baik tentang antenatal care yaitu sebanyak 42 responden $(73,7 \%)$, sedangkan yang memiliki pengetahuan kurang yaitu sebanyak 15 responden $(26,3 \%)$. Hal ini menunjukkan bahwa responden sudah memiliki pengetahuan baik tentang antenatal care. Pengetahuan merupakan hasil dari "tahu" dan hal ini terjadi setelah seseorang melakukan penginderaan terhadap objek tertentu. Pengetahuan disini menyangkut segala sesuatu yang dipahami dan diketahui oleh responden tentang antenatal care. ${ }^{\left({ }^{(8)}\right.}$

Pada hasil penelitian pada ibu hamil trimester III tentang antenatal care sebagian besar memiliki pengetahuan baik, ini disebabkan ibu hamil trimester III sudah mengetahui lebih jauh tentang antenatal care dan informasi yang didapat diperoleh dengan baik, baik dari media massa, teman, keluarga maupun pihakpihak terkait yang berkewajiban memberikan penyuluhan. Pengetahuan responden yang masih kurang karena jarang menerapkan pengetahuan yang dimiliki khususnya tentang antenatal care. Pada dasarnya suatu pengetahuan menjadi sempurna dan teringat apabila dipahami dan dilaksanakan. ${ }^{(10)}$

Berdasarkan tabel 3 distribusi frekuensi berdasarkan jumlah pelaksanaan $\mathrm{K} 4$ ibu hamil trimester III di Puskesmas Gerung, didapatkan mayoritas responden melakukan $\mathrm{K} 4$ sebanyak 50 responden $(87,7 \%)$ dan minoritas responden tidak melakukan K4 sebanyak 7 responden $(12,3 \%)$.

Pelaksanaan atau tindakan adalah suatu sikap yang belum otomatis dalam suatu tindakan, untuk mewujudkan sikap menjadi suatu perbuatan yang nyata maka diperlukan faktor pendukung lain. Tindakan merupakan suatu aturan yang mengadakan hubungan erat antara sikap dan tindakan yang didukung oleh sikap yang mengatakan bahwa sikap merupakan pandangan atau perasaan disertai kecenderungan untuk bertindak.

Tindakan mempunyai tingkatan yaitu Persepsi (perception) mengenal dan memilih berbagai objek sehubungan dengan tindakan yang akan diambil.Respon Terpimpin (guided response), dapat 
melakukan sesuatu sesuai dengan urutan yang benar dan sesuai dengan contoh. Mekanisme (mechanisme), apabila seseorang telah dapat melakukan sesuatu dengan benar secara otomatis atau sesuatu itu merupakan kebiasaan, maka ini sudah mencapai praktek tingkat tiga. Adopsi (Adoption), adopsi adalah tindakan yang sudah berkembang dengan baik yang berarti bahwa tindakan sudah dimodifikasi dengan baik tanpa mengurangi kebenaran tindakan lanjut.

Dalam penelitian ini dapat dilihat mayoritas pelaksanaan K4 dilakukan dengan baik terlihat dari kepatuhan ibu hamil trimester III melakukan pemeriksaan kehamilan (antenatal care) secara teratur ketenaga kesehatan seperti bidan. Tindakan merupakan presentasi nyata dari pengetahuan dan sikap yang dimiliki oleh seseorang.

Berdasarkan uji statistik diperoleh nilai $\mathrm{p}=$ 0,000 yaitu ada hubungan yang bermakna secara statistik ( $\mathrm{p}<0,05)$ artinya ada hubungan antara pengetahuan ibu hamil trimester III tentang antenatal care terhadap pelaksanaan $\mathrm{K} 4$ atau dengan kesimpulan Ho ditolak. Artinya bahwa terdapat perbedaan proposi ibu yang memiliki pengetahuan kurang dengan ibu pengetahuan baik dalam kunjungan $\mathrm{K} 4$ atau ada hubungan yang siginfikan antara pengetahuan ibu dengan kunjungan K4. Hal ini sejalan dengan hasil penelitian yang didapatkan oleh Erlinawati (2017) dan Permatasari (2017) bahwa ada hubungan signifikan antara pengetahuan ibu hamil dengan pelaksanaan kunjungan K4.(5)(12) Sedangkan hasil penelitian Florence (2014) menunjukkan bahwa untuk analisis bivariatnya di jelaskan bahwa ibu hamil yang pengetahuannya tinggi berjumlah 124 orang $(96,1 \%)$ lebih tinggi dari pada ibu hamil yang pengetahuannya rendah yang berjumlah 5 orang $(3,9 \%)$, hasil uji chi square diperoleh $\mathrm{p}$ value 0,566 yang bearti bahwa tidak ada hubungan yang bermakna antara pengetahuan ibu hamil dengan kepatuhan pemeriksaan kehamilan. ${ }^{(6)}$ Peneliti berasumsi bahwa ibu hamil yang memiliki pengetahuan tinggi cenderungakan lebih banyak memanfaatkan pelayanan antenatal, hal ini disebabkan karena ibu yang berpengetahuan tinggi cenderung peduli dengan kesehatannya dan terdapat perhatian terhadap keadaan kehamilannya. Hal ini sangat berpengaruh terhadap pemeriksaan yang dilakukan oleh ibu hamil. Semakin tinggi pengetahuan tentang pemeriksan kehamilan maka semakin tinggi kecenderungan orang untuk melakukan pemeriksaan kehamilan. Maka peneliti berasumsi bahwa dengan pendidikan yang tinggi maka pengetahuan yang dimiliki akan semakin baik dan akan mempengaruhi seseorang dalam menerapkannya terhadap tindakan tindakan.

\section{KESIMPULAN}

Dari hasil penelitian hubungan pengetahuan ibu hamil trimester III tentang antenatal care terhadap pelaksanaan K4. Maka dapat ditarik kesimpulan bahwa Berdasarkan uji statistik diperoleh nilai $\mathrm{p}=$ 0,000 yaitu ada hubungan yang bermakna secara statistik ( $\mathrm{p}<0,05)$ artinya ada hubungan antara pengetahuan ibu hamil trimester III tentang antenatal care terhadap pelaksanaan $\mathrm{K} 4$ atau dengan kesimpulan Ho ditolak. Peneliti berasumsi bahwa dengan pendidikan yang tinggi maka pengetahuan yang dimiliki akan semakin baik dan akan mempengaruhi seseorang dalam menerapkannya terhadap tindakan tindakan.

\section{DAFTAR PUSTAKA}

1. Ariyanti, I. Pengetahuan Ibu Hamil Yang Berhubungan Dengan Pemeriksaan Kehamilan Trimester III Di Wilayah Kerja Puskesmas Kecamatan Cipayung, Tahun 2016. Jurnal Bidang Ilmu Kesehatan Vol. 11, No. 1, Juni 2018: 762- 771

2. Departemen Kesehatan Republik Indonesia. Visi Misi Indonesia Sehat. Jakarta: Departemen Kesehatan RI. 2010

3. Departemen Kesehatan Republik Indonesia. Standar Pelayanan Kebidanan. Jakarta: Dirjen Binkesmas. 2017.

4. Dinas Kesehatan Kabupaten Lombok Barat. Laporan Pemantauan Wilayah Setempat Kesehatan Ibu Dan Anak Kabupaten Lombok Barat 2020. Lombok Barat: Dikes Lombok Barat. 2018

5. Erlinawati. Faktor-Faktor Yang Berhubungan Dengan Pelaksanaan K4 Di Wilayah Kerja Puskesmas Lubuk Jambi Kabupaten Kuantan Singingi. 2017; 01:139-151

6. Florence, L. Determinan Kepatuhan Anc Ibu Hamil Dan Upaya Pencegahan Anemia Kehamilan Di Puskesmas Buntok Tahun 2014. Universitas Respati Indonesia. Jakarta. 2014

7. Kusuma, R. Hubungan Pengetahuan Dan Sikap Ibu Hamil Tentang Antenatal Care Dengan Kunjungan K4. Jurnal Psikologi Jambi. 2018;03(01): 24-32.

8. Mamalanggo, A. Rumayar, A, Maramis, R. Hubungan Antara Pengetahuan, Sikap Ibu Serta Dukungan Petugas Kesehatan Dengan Kunjungan Antenatal Care (Anc) Di Puskesmas Ranotana Weru Kota Manado. Jurnal Kesmas;8(7). 2019:221-227

9. Manuaba,I.B.G. Ilmu Kebidanan Penyakit Kandungan Dan Keluarga Berencana Untuk Pendidikan Bidan. Jakarta: Egc. 2012

10. Notoatmodjo, S. Promosi Kesehatan Dan Ilmu Perilaku. Jakarta:Rineka Cipta. 2007

11. Notoatmodjo, S. Promosi Kesehatan Dan Perilaku Kesehatan. Jakarta: Rineka Cipta. 2012.

12. Permatasari, D. Hubungan Tingkat Pengetahuan Dengan Sikap Ibu Hamil Dalam melakukan Kunjungan K4 Di Desa Kalimo’ok Kecamatan 
kalianget Kabupaten Sumenep. Jurnal Kesehatan Wiraraja Medika. 2017:3-8

13. Syafrudin. Promosi Kesehatan Untuk Mahasiswa

Kebidanan. Jakarta: Cv. Trans Info Media. 2009 